\title{
鉄筋コンクリート造連層有開口耐震壁の変形能の評価法 DEFORMATION CAPACITIES OF REINFORCED CONCRETE CANTILEVER WALLS WITH OPENINGS
}

\author{
加藤大介*, 杉下陽一**, 小倉宏一**, 大谷裕美** \\ Daisuke KATO, Yoichi SUGISHITA, Koichi OGURA \\ and Hiromi OOTANI
}

\begin{abstract}
The objectives of this study were to examine deformation capacities of cantilever shear walls with openings experimentally and to evaluate the design equation (truss-arch analogous model), which had been developed to estimate the shear strength of shear walls with openings, for the estimation of the deformation capacities of cantilever shear walls with openings. Six reinforced concrete cantilever shear wall specimens with openings, which were designed to fail in flexure at their bases, were tested under static reversal load. Variables were peripheral ratios of the opening $(0.3,0.4$ and 0.5$)$, the location of the openings and the reinforcement of the side walls beside the opening.
\end{abstract}

Keywords : reinforced concrete, wall with opening, shear strength, deformation capacity static loading test, cantilever wall, seismic design

鉄筇コンクリート, 有開口壁, せん断強度, 変形能, 静加力実験, 連層壁, 而震設計

1.はじめに

\section{1 本研究の背景}

本研究の目的は鉄筋コンクリート造連層有開口耐震壁の変形能の 評価法を確立することである。鉄筋コンクリート造有開口耐震壁は 日本建築学会によって提案された鉄筋コンクリート構造計算規準 [1]（以下 R C 規準）に従い設計されてきた。このR C規準では， 開口周比より計算される開口低减率によって強度および弾性剛性を 低减させる方法，および，補強筋量の算出方法が示されている。し かしながら，これらの方法は弾性理論に基づき示されており，終局 強度法に基づいた設計に応用することはできない。

筆者らは終局強度に基づいた有開口耐震壁の設計方法を開発する ために開口をもつ 1 層の耐震壁のせん断破壊実験を行い $[2,3]$, そ の検討を基に開口耐震壁の終局強度型設計法を提案した[4]。これ らの実験は主にさまざまな種類の開口がある壁のせん断耐力を評価 するために行われた。図-1はストラットとタイモデルを有開口壁に 適用したものであるが，文献 [4] で示した知見を示している。図一 l(a)は一般的なストラットとタイモデルであるが, 実験の結果, 開 口横の袖壁のコンクリートの斜めのストラットは，その圧縮力に釣 り合う水平方向のタイ (図中(1)）の反力が足りないために, 形成す ることができないということが分かった。すなわち，有開口耐震壁 の強度を算定するためには図-1 (b) で示されるモデルの方がより現
実的である。この場合，コンクリートの斜めのストラットの反カは， 梁主筋によって钓り合う。これより有開口耐震壁のせん断強度の算 出法として, 両側の袖壁の強度を合計する方法, さらに, 個々の袖 壁は図-1(b)に示されるようにモデル化されるべきであることが提 案されている。特に, 袖壁のせん断強度式を適用する際の壁高さの 評価が重要である。

\section{2 有開口柇罢壁のせん断強度式の再検㶦}

文献 [4] の方法は両袖壁のせん断強度の和を有開口耐震壁のせ ん断強度とするものであるが，実際には引張側の袖壁は曲げ降伏寸 ることが予想されるので，ここではより現実的なせん断強度の評価 法を検討した。付録 1 に本論文で用いた有開口耐震壁の各強度式を まとめて示しておく。

図-2 (a)〜 (c) は，過去に日本で行われた有開口耐震壁の実験結果 を用いて最大強度の実験値と計算值を比較したものである（出典は 文献 [4]に記述)。綐軸は実験值, 横軸は計算值であるが, いず れも曲げ強度計算值（付録 1 (5)）で除して基淮化されている。図2 (a) は仮想の無開口耐震壁のせん断強度を開口低减率 $\gamma$ により低減 したものである（付録 1 (2)）。付録 1 にその概要を示しているが、 無開口壁のせん断力は日本建築学会による鉄筋コンクリート造建物 の終局強度型設計指針（以下学会指針）[5]に示されているトラス とアーチの式より算出した。図よりこの方法は安全側ではないこと
* 新潟大学工学部建設学科 教授·工博

** 新潟大学自然科学研究科 博士課程前期大学院生
Prof., Dept. of Architecture, Faculty of Engineering, Niigata University, Dr. Eng. Graduate Student, Dept. of Architecture, Faculty of Engineering, Niigata University 


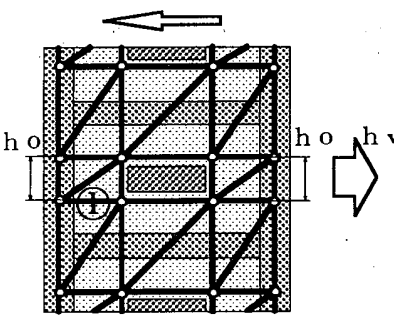

（a）ストラットとタイの基本モデル

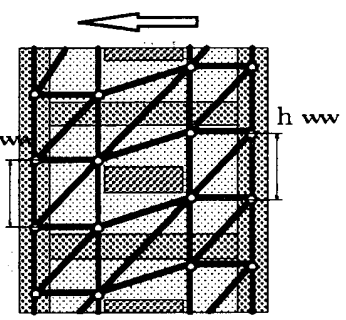

(b) 実験より修正されたモデル

図-1＼cjkstart有開口耐震壁の力の伝達モデル

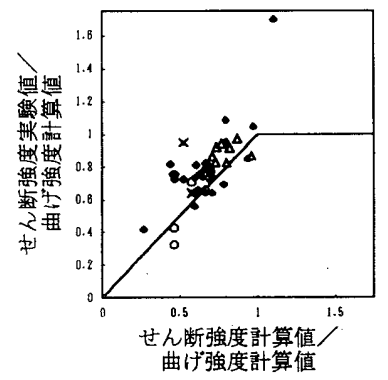

(a) 開口低減率を使う方法 $\left(\nu_{0}=0.7-\sigma_{B} / 200\right)$

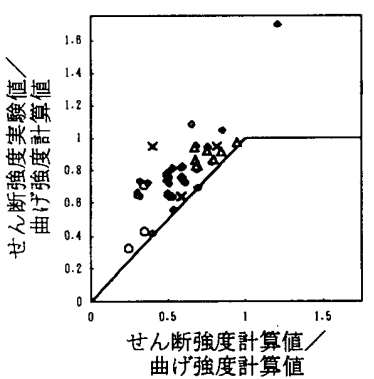

(c) 両側の袖壁の強度の和とする方法 $\left(v o=0.9-\sigma_{\mathrm{B}} / 200\right)$ 図-2 有開口耐震壁のせん断強度式の適用性の検証

が分かる。一方, 図-2(b) (c) は両側の袖壁の強度を合計する文献 [4] で提案された方法による結果を示している。ただし、文献 [4] と は異なり、袖壁の個々の強度はせん断強度と曲げ強度の最小值によ り得られたものとした（付録 1 (3))。両袖壁に作用する軸力は文献 [1]に示された方法で求めたが, 開口高さ中央位置での引張鉄筋 (斜め 筋を含む)より決まる最大引張軸力で打ち止めしている。図-2(b)は袖壁の せん断強度式に学会指針により提案されたせん断設計式を用いたも のである。図-2(c) も同様であるが、コンクリート強度有効係数と して学会指針で示されたものより高い值を採用している。具体的に は係数 0.7 を 0.9 に置き換えて，以下の式(1)を用いている。

$$
v_{0}=0.9-\sigma_{\mathrm{B}} / 200 \quad \text { (1) }
$$

これは有開口壁の両側の袖壁に作用する軸力は, 加力方向に従って 圧縮力と引張力が交互に作用する, すなわち変動軸力であるため, 圧縮方向の一定軸力を受ける無開口試験体の壁板に比ベコンクリー トの損傷が少ないことを考慮した結果である。なお，曲げ強度を計 算するための袖壁の高さは開口の高さとしている。

図-2(b) (c)より、学会指針そのままの係数を用いた場合 (図 (b))は安全側過ぎ、式(1)に示した有效係数を用いた方(図 (c))が安
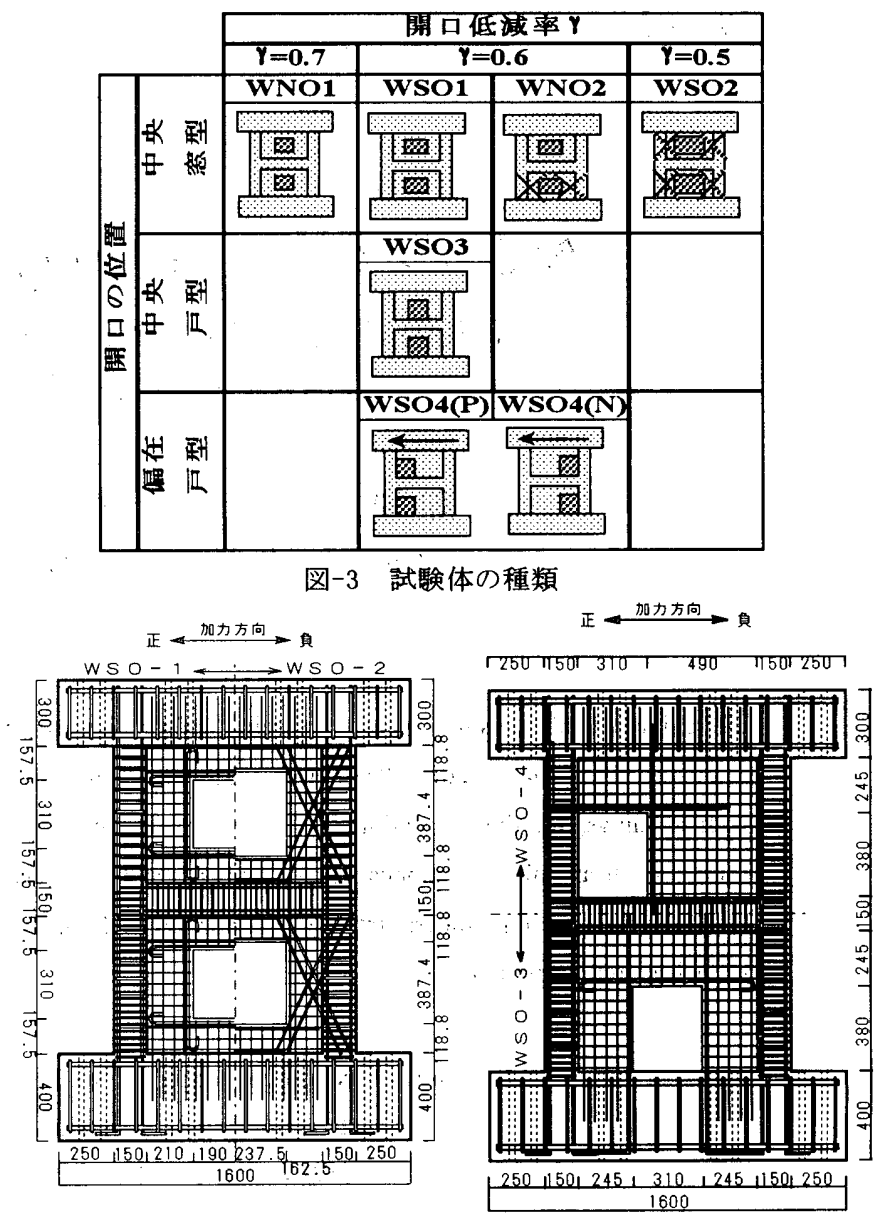

$\begin{array}{ll}\text { (a) WS01 (左) とWS02 (右) } & \text { (b) WS03 (上) とWS04 (下) }\end{array}$

図-4 試験体の配筋図の例

全側でなおかつ精度のよいせん断強度の設計式であると判断できる。 コンクリート強度の有効係数を通常用いられているものと異なるも のを適用することについては議論があろう。しかしながら、ここで は実験結果をより精度よく評価することを第一と考えた。なお、実 際の設計においては通常使用されている有効係数を用いることは安 全側であり、なんら問題ない。

\section{3.本研究の目的}

以上の成果により有開口耐震壁は曲げ降伏する鞋性のある壁とし て設計することはできる。しかし，曲げ強度および変形能に及ぼす 開口の効果は, 設計方法を検証するのに十分に広く研究されてきて いない。特に, 曲げ降伏する連層耐震壁の実験が不足していると言 わざるを得ない。本研究ではこの観点より, 有開口連層耐震壁静加 力実験を行い, 連層壁の曲げ強度と変形能に及ぼす開口の影響を検 討した。本報では特に変形能の検討結果を報告する。

\section{2. 鉄筋コンクリート适連莌有開口耐罢壁の静加力实験 \\ 2. 1 試験体}

6 体のRＣ造有開口壁の静加力実験を行った。これらの実験は96 年 [6] と97年 [7]に行っており，96年に行った 2 体をWNOシ リーズ，97年に行った他の 4 体をW S Oシリーズと呼んでいる。い ずれの試験体も 2 層 1 スパンの連層壁であるが, 一番上の梁は多層 酎震壁の効果も想定して, 均一な横力を壁に与えるために, 意図的 
に㓮で強固なものとした。断面と壁, 柱, 梁の配筋を表-1 (a) (b) (c) にそれぞれ示す。

図-3に試験体の種類を示す。主なパラメーターは開口の大きさと その位置およびせん断補強筋としての斜め筋の有無である。開口の 大きさはせん断强度の低減倸数で表現されており，0.5から0.7の間 で変化させた。開口の位置は, 中央空型開口のもの, 中央戸型開口 のもの, 偏在戸型開口のものを想定した。偏在戸型開口の試験体は, 左右対称ではないために正加力時と負加力時で挙動が全く違う結果 となった。この観点より，本報告ではこの試験体の挙動は加力方向 によって別々に検討し, 正加力時には試験体W S O 4 (P) と呼び, 負加力時には試験体W S O $4(\mathrm{~N})$ と呼ぶことにする。

筆者らは文献 $[2,3]$ で、有開口耐震壁のせん断強度のみを上昇 させる方法として、開口左右の袖壁に適切に配筋された斜め筋が有 効であることを実験的に示した。これらの斜め筋は、曲げ強度を上 昇させないために試験体の基礎部分には定着していないが、袖壁部 分が破壊するときに引張力を負担できるように、袖壁の外部に有効 に定着される必要がある。図-3の斜めの線はこの斜めせん断補強筋 を表している。

試験体の寸法と配筋例を図-4に示す。開口周比を 0.3 とした試験 体WNO 1 は開口周囲の補強筋をR C 規準に従って配筋した。ただ し 1 層部分の開口横補強筋は両側の柱まで延長させ, 袖壁のせん断 抵抗に有効であると想定した。開口周比 0.4 の試験体WNO2には 従来の開口補強筋 (\#型) の代わりに袖壁のせん断補強筇としてD 6 鉄筋を12本斜めに配筋した。ただし，これらの斜め筋は試験体の 基礎には定着していないため, 壁全体としての曲げ強度には寄与し ない。

開口周比0.4の試験体W S O 1 では開口周囲に従来型の補強筋を 入れた。しかし，試験体W SO 1 の横補強筋は試験体WNO 1 とは 異なり柱まで延長させないものとした。開口周比0.5の試験体W S O 2 の開口補強筋はD 6 を4本従来型で入れ，さらにD 6 を 8 本左右 の袖壁に斜めに入れた。

試験体W S O 3 は開口周比を0.4としスパン中央部に戸型の開口 をおいた。試験体W S O 4 は偏在戸型開口としたので独立柱が存在 する。この 2 つ試験体は R C 規準により従来型の開口補強筋を配 筋した。しかし, 開口補強筋は基礎に定着しているため曲げ強度に 寄与する。

表-2に鉄筋とコンクリートの材料諸元を示す。すべての試験体は 曲げ降伏するように設計した。すなわち、付録 1 (5)に示す曲げ強 度が付録 1 (2)に示す開口低減率を用いたせん断強度を下回るよう にした。各試験体の曲げ強度とせん断強度の計算值を表-3に示して おく。

\section{2 加力方法と酎定}

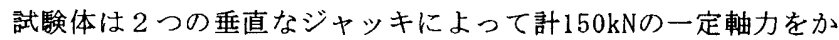
けた。左右交番の水平力は上部加力梁の端，下の基礎から $1900 \mathrm{~mm} の$ 高さに加えた。また, 水平力は加力点の水平変形角 $1 / 400,1 / 200$, $1 / 100,1 / 67,1 / 50,1 / 25(\mathrm{rad})$ での繰り返し載荷とした。各層の水 平変位, 柱の鉛直変位は電気式変位計により測定した。また, 柱, 壁筋の歪も測定した。

\section{3 実験結果の概要}

図-5に試験体のせん断力一曲げ変形角関係およびせん断力一せん (a)試験体柱部分の断面と配筋

$$
\text { 表-1 試験体の諸元 }
$$

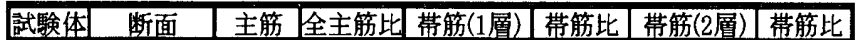

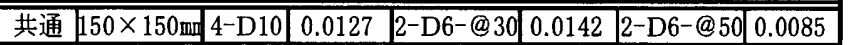
(b)試験体壁部分の断面と配筋

\begin{tabular}{|c|c|c|c|c|c|}
\hline 試験体 & 開口周比 & 壁厚 & 壁筋 & 開口補強(1層) & 開口補強(2層) \\
\hline WNO1 & 0.3 (中央) & \multirow{6}{*}{$75 \mathrm{~mm}$} & \multirow{2}{*}{$\begin{array}{c}2- \\
\phi 4-@ 50\end{array}$} & 4-D10 \#型(横延長) & 4-D10 \#型 \\
\hline WNO2 & 0.4 (中央) & & & 12-D6 X型 $\left(60^{\circ}\right)$ & 4-D10 \#型 \\
\hline WSO1 & 0.4 (中央) & & \multirow{4}{*}{$\begin{array}{l}\text { (壁筋比 } \\
0.0069 \text { ) }\end{array}$} & \multicolumn{2}{|c|}{ 4-D10 \#型 \& 4-D6 \#型 } \\
\hline WSO2 & 0.5 (中央) & & & \multicolumn{2}{|l|}{ 8-D6 X型 $\left(68^{\circ}\right) \&$} \\
\hline WSO3 & 0.4(中央戸型) & & & \multicolumn{2}{|c|}{ 3-D13 \#型 } \\
\hline $\mathrm{NSO} 4$ & $\Delta A$ 原在巨 & & & \multicolumn{2}{|c|}{ 2-D13 \#型 } \\
\hline
\end{tabular}

X型補強筋の角度は水平面からの角度

(c)試験体梁部分の断面と配筋

\begin{tabular}{|c|c|c|c|c|c|}
\hline 試験体 & 断面 & 主筋 & 全主筋比 & あばら筋 & あばら筋比 \\
\hline \hline 共通 & $150 \times 150 \mathrm{~mm}$ & $4-\mathrm{D} 10$ & 0.0127 & 2-D6-@50 & 0.0085 \\
\hline
\end{tabular}

表-2 材料の性質

\begin{tabular}{|l|c|c|c|c|c|c|c|}
\cline { 2 - 9 } \multicolumn{1}{c|}{ (a)鉄筋の性質 } & \multicolumn{4}{c|}{ 験体WNシリーズ } & \multicolumn{4}{|c|}{ 試験体WSシリーズ } \\
\hline 鉄筋名 & $\phi 4$ & D6 & D10 & $\phi 4$ & D6 & D10 & D13 \\
\hline 降伏応力度 $(\mathrm{Mpa})$ & 530 & 317 & 330 & 521 & 331 & 348 & 354 \\
\hline 最大応力度(Mpa) & 560 & 478 & 469 & 629 & 482 & 492 & 648 \\
\hline
\end{tabular}

(b)コンクリートの性質

\begin{tabular}{|l|r|r|r|r|r|r|}
\hline 試験体名 & WNO1 & WNO2 & WSO1 & WSO2 & WSO3 & WSO4 \\
\hline 圧縮強度 $(\mathrm{Mpa})$ & 24.9 & 27.2 & 31.2 & 30.4 & 31.3 & 32.9 \\
\hline 強度時歪度 $(\mu)$ & 2187 & 2417 & 2588 & 2575 & 2591 & 2646 \\
\hline
\end{tabular}

表-3 試験体の曲げ強度とせん断強度計算值

\begin{tabular}{|l|r|r|r|r|r|r|r|}
\hline & WNO1 & WNO2 & WSO1 & WSO2 & WSO3 & WSO4(P) & WSO4(N) \\
\hline 壁基部曲げ強度 & 137 & 137 & 138 & 138 & 138 & 138 & 121 \\
\hline せん断強度(開口低減率) & 289 & 322 & 284 & 265 & 284 & 291 & 291 \\
\hline (せん断強度/曲げ強度) & $(2.11)$ & $(2.35)$ & $(2.06)$ & $(1.92)$ & $(2.06)$ & $(2.11)$ & $(2.40)$ \\
\hline
\end{tabular}

表-4 変形能の実験値一覧

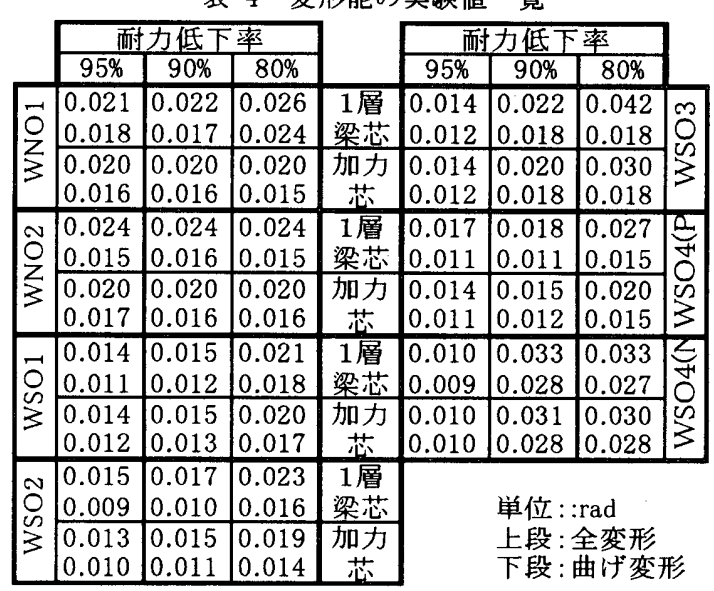

断変形角関係を 1 層部分について示す。ここで, 曲げ変形角は 1 層 梁芯での回転角, せん断変形は全体変形から曲げ変形を差し引いて 算出した。全変形角は 1 層の梁芯位置の水平変形を下基礎の危険断 面までの高さで除したものである。なお，加力点での荷重一水平関 倸は文献 $[6,7]$ に示してある。 


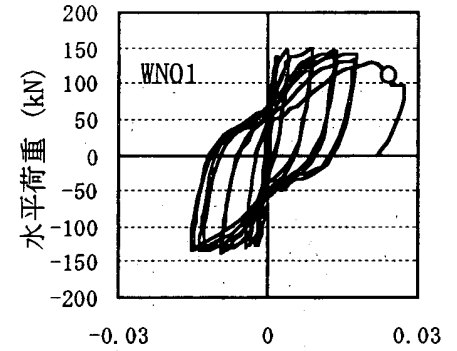

曲げ変形角 (rad)

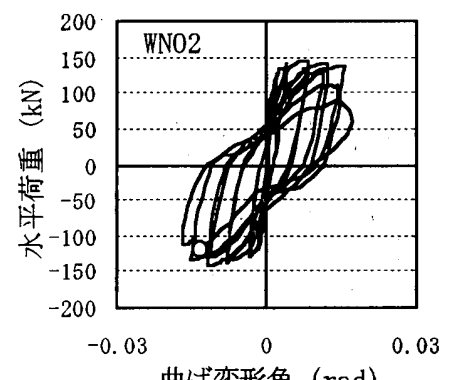

曲げ変形角 $(\mathrm{rad})$

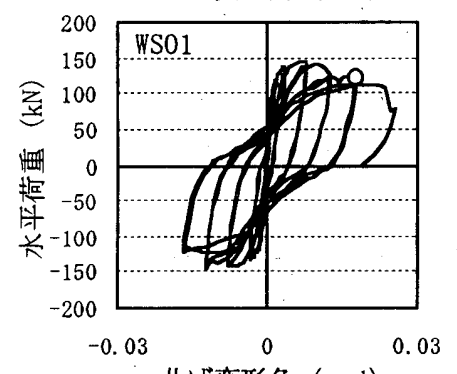

曲げ変形角 (rad)
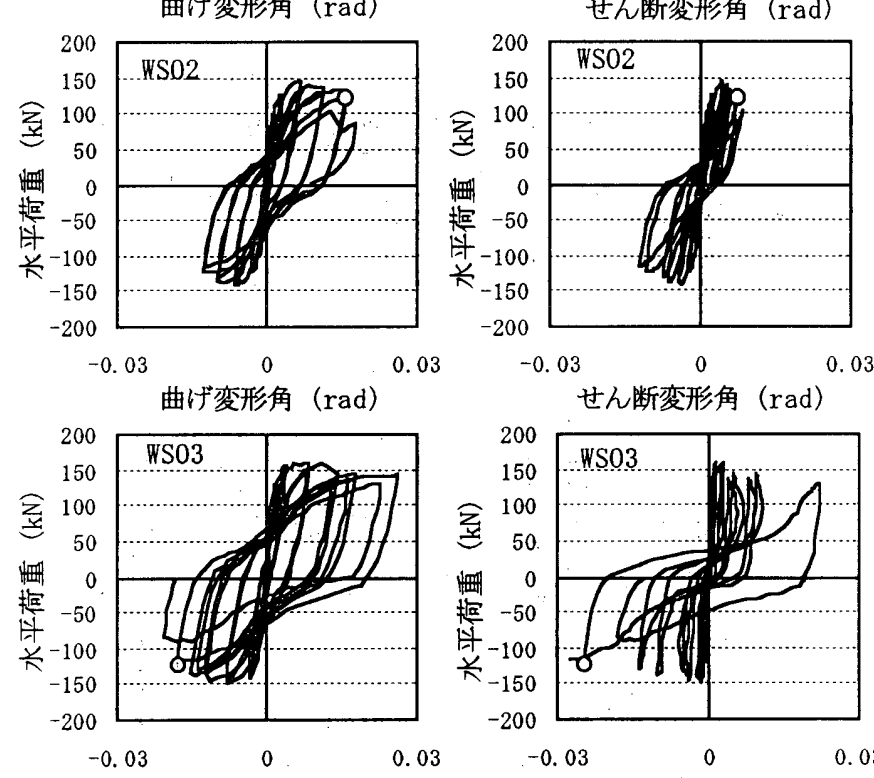

曲げ変形角 $(\mathrm{rad})$

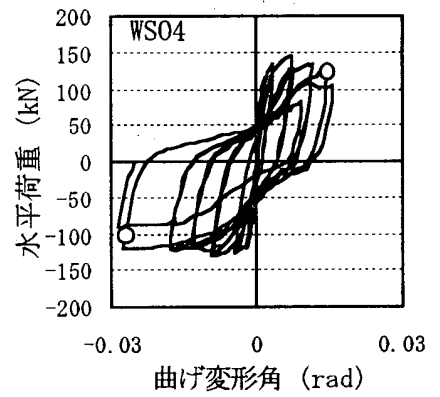

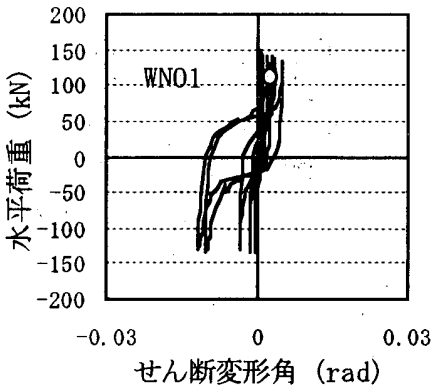

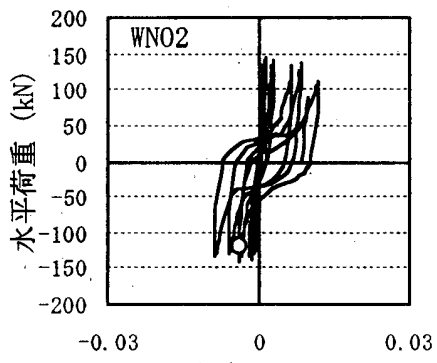

せん断変形角 $(\mathrm{rad})$
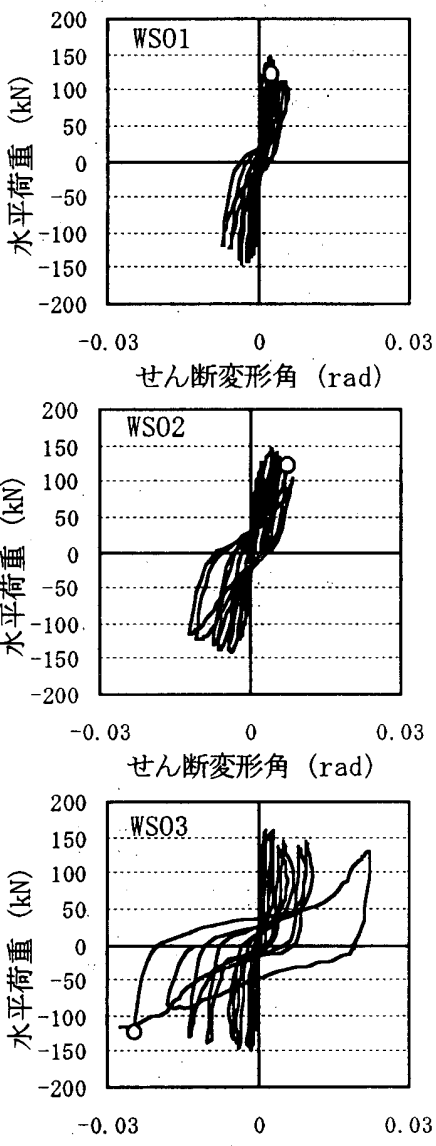

せん断変形角 $(\mathrm{rad})$

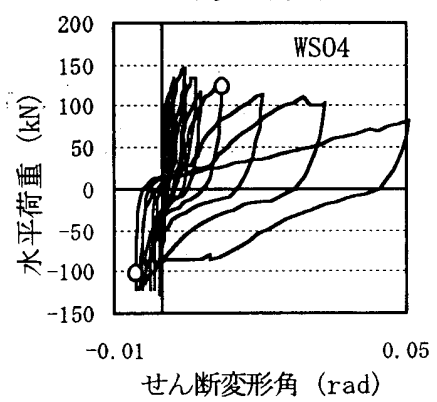

せん断変形角 $(\mathrm{rad})$

図-5 1 層部分のせん断力-曲げ変形, せん断変形関係

1 サイクル $(1 / 400 \mathrm{rad})$ 時にはすべての試験体で柱脚部に曲げひび 割れが生じ，袖壁には開口隅角部からせん断ひび割れが生じた。3 サイクル $(1 / 200 \mathrm{rad})$ 時には多くの曲げひび割れが壁脚部に見られ, すべての試験体の主筋が降伏した。

どの試験体も変形角 $1 / 100(\mathrm{rad})$ まで勒性の良い举動を示し，1/10 $0(\mathrm{rad})$ を越えてからは履歴ループの中にピンチングタイプ举動が見 られた。試験体WNO 1 はl $/ 33(\mathrm{rad})$ 一向かい最初のサイクルで耐 力の低下が著しくなった。一方, 試験体WNO 2 は1/50 (rad) サイ クルを繰り返したところで次第に耐力が低下していった。W O O リーズの挙動は, 斜め筋のない試験体W S O 1 の举動は, 同じく斜 め筋のない試験体WNO 1 の举動に, 斜め筋のある試験体W S O 2 の举動は斜筋のある試験体WNO 2 と類似していた。空型開口を 持つこれら 4 つの試験体の全体変形に対する曲げ変形の比は80〜9 $0 \%$ 程度だった。一方, 中央戸型の開口を持つW S O 3 のせん断変 形成分の比は空型開口の試験体より大きいものとなった。これは, 戸型開口の試験体では危険断面での断面積が久損するので, 危険断 面でのすべり変形が大きくなるからである。

偏在戸型開口を有する試験体W S O 4 の挙動はどの試験体とも異 なり, 正加力と負加力で非対称の形となった。独立柱が引っ張り軸 力を受ける負加力時には良好な鞋性举動を示した。しかしながら， 独立柱が圧縮軸力を受ける正加力時には, 最大耐力が負加力時より 大きくなったが, 最大耐力以降の耐力低下が著しくなった。また, 試験体のせん断変形は独立柱が圧縮となる正加力時は大きかった。

\section{2: 4 変形性能のまとめ}

表-4は最大耐力の $95 \% ， 90 \% ， 80 \%$ 低下時での全体変形角， 曲げ変形角を示している。前述の通り曲げ変形角はその位置での回 転角とした。2 箇所の変形角（1 層中心，加力点での変形角）を示 した。ただし，試験体WS O 4 を除いて，正負の加力方向の 2 つの 変形角の小さい方の值を各試験体の值としている。試験体W SO 4 は左右対称ではないので，両方の値を示した。表-4ではいくつかの 点での変形角を示しているが，本研究では一般に使われている復元 力が最大耐力の $80 \%$ に低下した点を勒性限界点と定義する。図-5 の丸印はこれらの勒性限界点を示している。実際の設計においては, 1 層での曲げ変形角が最も重要である。この観点から, 以降本報で は, 勒性限界点での 1 層部分の曲げ変形角を重視して検討を進める。

\section{3、変形能の評任法の現状およびその問題点}

\section{1 開口低淢晕を使う方法の問題点と適用簿囲}

学会指針では, 無開口耐震壁の変形能を曲げ耐力と等しいせん断 耐力を与えるコンクリート有効係数を用いて評価寸る方法が示され ている。本研究では同手法を有開口壁の変形能を評価するために適 用し, 変形能とコンクリート有効保数の間の関倸を議論する。

図-6は、縋軸に曲げ耐力と等しいせん断耐力を与えるコンクリー 卜強度有效保数 $(\nu \mathrm{m})$ を潜在的なせん断強度（文献 [5] でいう非 ヒンジ領域のせん断強度）を与えるコンクリート強度有効倸数（ o）で除したものを、横軸に終局変形角の実験值をとり、比較した ものである。図-6(a1)（a2）は，せん断強度式に付録l(2)で示したせ 儿断強度の低减率 $\gamma$ と学会指針の無開口耐震壁のせん断強度式を併 用したときのものである。なお、曲げ耐力は付録 1 (5)で示した有開 口耐震壁試験体の 1 階基硠面（危険断面）での全体曲げ強度時 


\begin{tabular}{|llll|}
\hline OWSO1 & $\square$ WSO2 & $\Delta$ WSO3 & $*$ WSO4(P) \\
$\times$ WSO4$(\mathrm{N})$ & $\diamond$ WNO1 & + WNO2 &
\end{tabular}
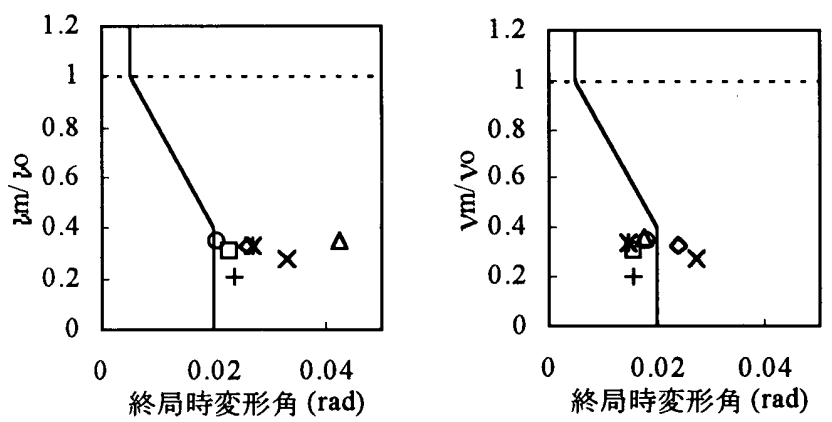

(a) 開口低减率を使った場合

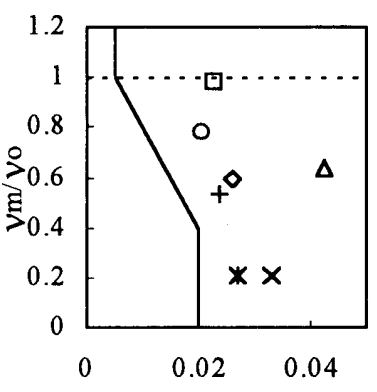

終局時変形角 $(\mathrm{rad})$

(b1) 1 層の全変形 (b) 両袖壁の強度の和によりせん断強度を求めた場合

図-6 せん断強度と曲げ強度を一致させるためのコンクリート強度 の有効係数と変形能実験值の比較

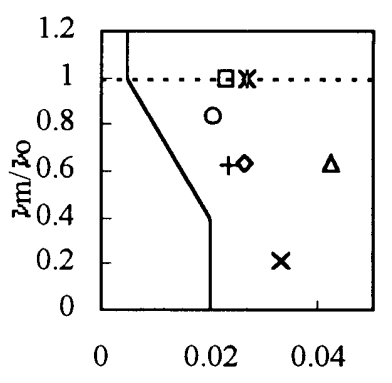

終局時変形角 $(\mathrm{rad})$

(a) 1 層の全変形

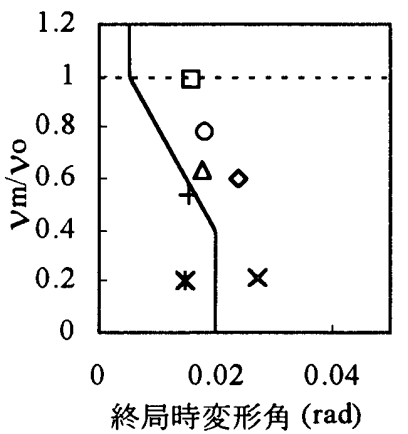

（b2）1 首の曲げ変形

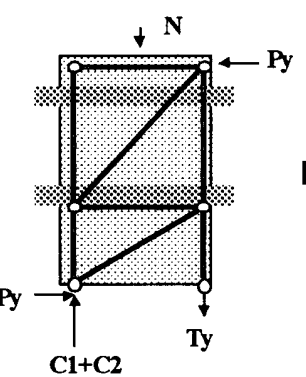

(a) 無開口耐震壁のモデル

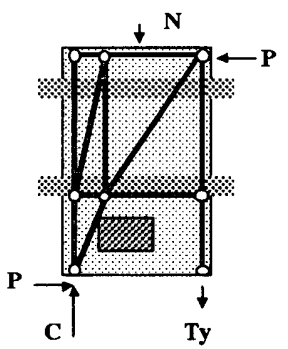

(c) 極端なモデルl (TypeF)

$\theta \mathbf{f}$

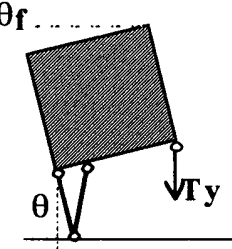

$\theta \mathbf{f}=\theta$

$\mathrm{M}=\mathrm{M} \mathrm{v}$

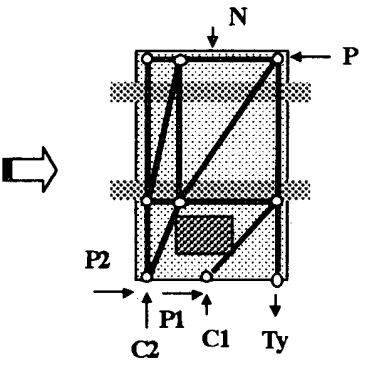

(b) 有開口耐震壁のモデル

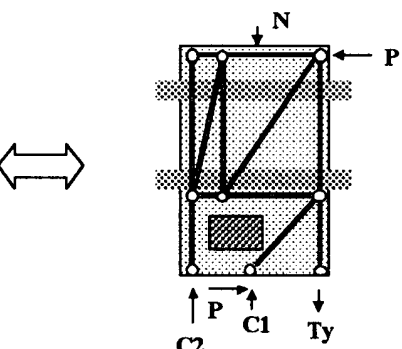

(d) 極端なモデル2 (TypeFS)
(e)TypeFの強度と変形機構 $\quad$ (f) TypeFSの強度と変形機構

図-7 有開口耐震壁の単純化されたストラットとタイのモデル

のものである。学会指針で示されている本設計式の原型は, 無開口 耐震壁を対象に提案されており，曲げ変形ではなく全変形を用いて 安全性が検証されている。この観点からは, 図(a1)で全て安全側な ので，開口低減率を用いる方法も設計に用いることもできるという 議論もあろう。しかしながら, 有開口耐震壁の場合は、無開口耐震 壁に比べ勒性限界時のせん断変形成分が大きくなる危険性があり， 本論文では低減率を使うやり方は危険側であると判断する。ただし， 試験体WNO 1 は曲げ変形を使ってもこの手法で安全側であること から，斜矨のない開口周比 0.3 以下の中央開口をもつ耐震壁は 開口低減率を用いる手法を適用可と判断できる。

\section{2 文萳 [4] のせん断強度莮定法を使う方法の問題点}

図-6(b1) (b2) は, 文献 [4] を参考にし，有開口壁のせん断耐力 を両袖壁の強度の和として得る方法を用いて, 同じ関係を示したも のである。ただし, 両袖壁の強度は曲げ強度とせん断強度の小さい 方とした（付録 1 (3)) 。また, せん断強度式に用いる非ヒンジ領 域のコンクリートの有効強度係数 $v$ 。は式(1)に示したものとしてい る。この方法によると、圧縮側の変動軸力を受ける袖壁はせん断強 度の方が曲げ強度よりも低くなるため、せん断強度でその袖壁の強 度が決まる傾向にあるが、引張側の変動軸力を受ける袖壁は、曲げ 強度が低下するため、曲げ強度でその袖壁の強度が決まる傾向にあ W S O 4 の負方向）のみで，これは斜め筋のない開口周比 0.3 
る。従って、一般的な有開口耐震壁では、その耐震壁としてのせん 断強度は、压縮側の袖壁のせん断強度と引張側の袖壁の曲げ強度の 和となる。図-6(b)では全ての試験体で縦軸が 1 以下、すなわち、 有効係数 $を$ を。とした計算した耐震壁としてのせん断強度は、全 体曲げ強度時のせん断力を上回っていることを示している。係数を $v \mathrm{~m}$ まで下げてせん断強度を計算すると、耐震壁としてのせん断強 度が全体曲げ強度時のせん断力と一致することになる。

図 (b1) (b2) は図(a1)（a2）と比べ，よりよい相関関倸が見られるが, 実際の設計で重要となる 1 層曲げ変形角のデータを使った図 (b2) に おいては，2つの危険側のデータがあり，このままでは設計式とし

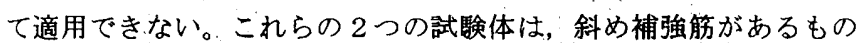
と, 独立柱が圧縮力を受ける正加力時の偏在戸型開口のものである。

\section{4. 変形能の評面法の提案}

\section{1 検討用のモデルおよび設計法}

この問題を議論するために, 図-7(a)（b)に示した単純化したモデ ルを検討する。図(a)は無開口壁のストラットとタイモデルを示し ている。このモデルでは、壁䋛筋は両側の柱位置に集中させ、また、 壁横筋は上下の梁位置に集中させ、せん断力は 1 つの斜めストラッ トによって伝えられると仮定したモデルである。このとき、曲げ耐 力 $\mathrm{P} \mathrm{y}$ は, 縦方向の引っ張りのタイが降伏力 $\mathrm{T} \mathrm{y}$ に達したときの耐 力として定義される。一方, 図(b) は有開口壁の単純化したストラ ットとタイモデルを示している。簡略化のため, 開口は 1 層部分の みを考慮した。このモデルは、耐震壁としてのせん断力をそれぞれ の袖壁に設定した $2 つ の$ 斜めストラットによって伝えられると仮定 したものである。なお、このモデルの耐震壁としてのせん断力を負 担する役割を持つ袖壁の圧縮ストラットの位置の詳細を付録 2 に示 しておく。

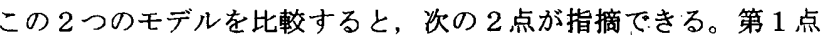
目は強度についてであるが, 図(b)に示した有開口耐震壁では，圧 縮反力C 1 が存在するために, 図(a)の無開口壁のモデルの曲げ耐 カ $\mathrm{P} \mathrm{y}$ を達成することはできないという点である。C 1 は圧縮反力 の一つで，もともと圧縮柱の中央に作用していたものであるが，開 口により壁板の中に移動することになり，この結果，曲げ強度が低 下する。第 2 点目は, 変形機構についてであるが, 図(b)のモデル においては引張柱が引張降伏後も水平移動変形, すなわち， 1 層 1 スパンの耐震壁としてのせん断変形，が生じることである。これら の举動は両側の袖壁によるせん断力抵抗の負担比により影響を受け る。この観点から, 図-7 (c) (d) に示すような, 図-7 (b) の原型モデ ルにおける $2 つ の$ 極端なケースを検討する。図(c)のモデルは，せ ん断力が圧縮軸力を受ける左側の袖壁のみにより伝達されるもので ある。ここでは、このタイプの壁をFタイプ（曲げタイプ）と呼ぶ。 また, 図(d)のモデルは, 引張軸力を受ける右側の袖壁のみでせん

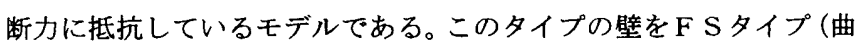
げせん断タイプ）と呼ぶ。これらの二つのモデルは，静定構造なの で, 引張柱の引張降伏による曲げ耐力と変形機構が容易に得られる。

図-7 (e) (f)に引張柱の降伏後の二つのタイプの强度と 1 スパンの 耐震壁としての曲げ変形 $(\theta \mathrm{f})$ と全変形 $(\theta)$ の関係を示す。図 $(\mathrm{e})$ に 示す $\mathrm{F}$ タイプでは，無開口壁と同じ曲げ強度 $(\mathrm{My})$ と变形機構を得 ることができる。しかしながら，F Sタイプでは，曲げ変形角と強
度は図 (f) 中に示すように無開口壁に比べ低減される。それは $\alpha$ と $\beta$ に依存，すなわち，開口の大きさと位置によって決定される。こ れより以下の二つの仮説が得られる。一つ目の仮説は，有開口壁を 曲げ降伏する無開口壁と同等に設計するためには，その壁はFタイ プとして設計すればよい，ということである。この時，せん断力は 圧縮軸力を受ける側の一つの袖壁のみによって抵抗されなければな らない。二番目の仮説は，その壁がFタイプとして設計ができない 場合には, 曲げ降伏する無開口壁と同等の性能をもつ壁としては設 計不可能となるが，その曲げ強度および変形能を図-7(f)に示すよ うに低减させることにより鞋性のある壁としての設計が可能となる， というものである。

\section{2 变形能の評田法の有効性の検証}

本報では、これらの仮説のうち，タイプ $\mathrm{F} の$ 変形能の評価法の有 効性を実験のデータにより検証する。図-8(a) (b) は試験体の全体曲 げ強度（付録1 (5)）とせん断強度が等しくなるときのコンクリート 有効保数と変形能害験值の関係を示したものである。ただし，有開 口壁のせん断強度は圧縮軸力が作用する側の袖壁のみ有効として算 出した（付録1 (4)）。図中の縦軸の值が 1 より小さい試験体は, 圧 縮側の袖壁のみでせん断力を伝達できる試験体，すなわち，Fタイ プに分類されることを意味している。なお、ここで，試験体WＳO 4 （P）, 寸なわち, 偏在戸型開口の試験体で独立柱が圧縮軸力を 受ける試験体においては, 耐震壁としての全体曲げ強度とせん断強 度が一致する点のコンクリートの有効強度係数 $v$ は算出不能であっ た。これは、 $v$ を増大させていくと、耐震壁としての全体曲げ強度 と耐震壁としてのせん断強度が一致する点が求まる前に、圧縮側の 独立柱の強度が曲げ強度で決まってしまい、Fタイプの壁のせん断 強度は圧縮側の袖壁（すなわち独立柱）のみの強度なので、それ以 上は耐震壁としてのせん断強度が増大しなくなるからである。そこ で，便宜上この試験体は縦軸 1 の点にプロットしてある。

1 層の曲げ変形角を用いた図(b)をみると, よい相互関係が見ら れ，また，設計式を下回る危険側のデータはないこと，すなわち， 本手法により有開口耐震壁を無開口耐震壁と同様に安全側に設計で きることが示されている。

ここで， 7 体の試験体の内 6 体が $F$ タイプに分類されたが, 前述 した試験体W SO 4 （P）が縦軸 1 の点にあり，本手法ではFタイ プとして無開口耐震壁と同様の方法では勒性のある耐震壁としては 設計できないことが分かる。これを勒性のあるタイプF S の耐震壁 として評価する方法については、さらに検討を進める予定である。

\section{5. 結諭}

（1）開口低减率を用いてせん断強度を求めるやり方で変形能を評 価する方法は危険側であった。ただし, 斜めせん断補強筋のない開 口周比 0.3 以下の中央開口をもつ耐震壁にはこの方法を適用して よい。

（2）有開口耐震壁を両袖壁に分離して変形能を評価する方法を提 案した。せん断力が圧縮側袖壁によってのみ伝達可能ならば（これ をFタイプと呼ぶ），曲げ強度は壁基礎面での平面保持解析により 求められる無開口耐震壁と同じものが期待される。また, Fタイプ の壁の変形能は, 圧縮側袖壁のせん断強度のみを考慮して, せん断 設計式に用いられるコンクリート強度有効係数により計算できる。 


\section{[参考文触]}

[1] 鉄筋コンクリート構造計算規準 - 同解説, 日本建築学会

［2］加藤大介，石塚正浩：鉄筋コンクリート造有開口壁のせん断 補強法に関する研究, 第10回コンクリート工学年次論文報告集 10-3, 1988年, pp. 403-408,

[3] 加藤大介，村上幸靖 : 鉄筋コンクリート造有開口壁のせん断 補強法およびせん断耐力評価に関する実験的研究, 第11回コンクリ 一下工学年次論文報告集11-2，1989，pp. 573-578，

[4] 加藤大介, 壁谷沢寿海, 小谷俊介, 青山博之：鉄筋コンクリ 一ト造有開口壁の耐震設計法, コンクリート工学論文集, Vol. 2, N o. 2，1991年, pp. 143-152

[5] 鉄筋コンクリート造建物の終局強度型耐震設計指針・同解説, 日本建築学会

［6］野田浩志, 杉下陽一, 加藤大介： R C 造連層開口壁の静加力 実験，第19回コンクリート工学年次論文報告集19-2，1997年，pp. 1 077-10882

[7] 大谷裕美, 杉下陽一, 加藤大介, 他： R C 造連層有開口壁の 静加力実験（その $1 \sim 3$ ）, 日本建築学会大会学術講演梗概集C-2 構造IV, pp. 821-826, 1998年.

\section{付録 1 有開口耐震壁の各強度式}

以下に有開口耐震壁の各強度式について簡単に示す。ただし、斜 め補強筋がある場合には、その定着が有効な場合には、曲げ強度お よびせん断強度に単純累加して評価する（詳細は文献 [4]）。

（1）無開口耐震壁のせん断強度式

無開口耐震壁のせん断強度は文献 [5] に従い、式(A1)による。 記号および詳細は文献 [5] を参照。

$$
\begin{aligned}
& \mathrm{Vu}=\mathrm{tw} \cdot 1 \mathrm{wb} \cdot \mathrm{ps} \cdot \sigma \mathrm{sy} \cdot \cot \phi \\
& \quad+\tan \theta(1-\beta) \mathrm{tw} \cdot 1 \mathrm{wa} \cdot v \sigma_{B} / 2
\end{aligned}
$$

（2）開口低減率を用いる場合のせん断強度

開口低減率を用いる場合のせん断強度は、開口を無視して(A1)で 求めた仮想無開口耐震壁のせん断強度に、文献 [1] による開口低 減率 $\gamma$ を乗じて求める。

（3）袖壁強度の和とする場合の有開口耐震壁のせん断强度

有開口耐震壁のせん断強度を、開口横の袖壁の強度の和として 求める場合の説明を付図-1に示寸。それぞれの袖壁の強度はせん断 強度と曲げ強度の小さい方とする。袖壁のせん断強度は文献 [4] に従い，付図-1の網掛け部分を対象にして求める。すなわち、袖壁 高さは式(A4)で与えられる。

$$
\begin{aligned}
\mathrm{h} w \mathrm{w} & =\mathrm{h} o+\mathrm{ht} & & \text { (引張側) } \\
& =\mathrm{h} \mathrm{o}+\mathrm{hc} & & \text { (圧縮側) }
\end{aligned}
$$

それぞれの袖壁のせん断強度式は(A1)の無開口耐震壁のせん断 強度式を用いて算定する。記号および詳細は文献 [4] を参照。

それぞれの袖壁の曲げ強度は、例えば付図ー1で示した引っ張り 側の袖壁の場合、 $\mathrm{b}^{-} \mathrm{b}^{\prime}$ 断面と $\mathrm{c}^{-} \mathrm{c}^{\prime}$ 断面の曲げ強度を平面保持を仮定 して求め、そのときのせん断力とする（文献 [4] 参照）。

（4）圧縮側の袖壁のみの強度とした有開口壁のせん断強度
基本的な考え方は (3) と同じであるが、有開口壁の強度を圧縮側 の袖壁のみを有効として算出したもの。すなわち、付図一の例では、 右側の袖壁の強度のみが全体の壁の強度となる。

（5）有開口壁全体の曲げ強度

有開口壁全体の曲げ強度は付図-1のa-a'断面の曲げ強度を平面保 持を仮定して求め、シアスパン長さで除して求める。本論文で示し た武験体では、シアスパン長さは基硌面 (a-a'断面) と加力点間距離 の1900mmである。

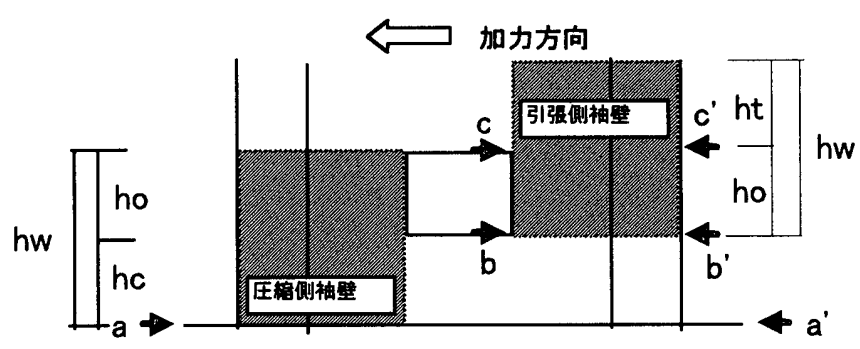

付図-1 有開口耐震壁のせん断強度算出用の袖壁の寸法

\section{付録 2 ストラットの位置の設定}

ここでは本文図-7で示した耐震壁としてのせん断力を負担する役 割を持つ袖壁の圧縮ストラットの位置の設定法、言い換えると、図

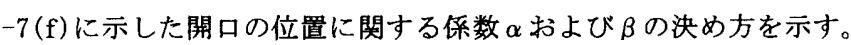
付図-2に強度を算定する際に想定する袖壁部分とストラットの位置 を示す。この想定する袖壁部分には図中で網掛けをしてあり、付図 ー1で示したものと同一である。圧縮力を負担するストラットは基本 的にこの斜線部を斜めに横切るものとして設定した。ただし、引張 力を負担するタイを引っ張り柱の中心に設定したので（図中破線の 矢印）、圧縮ストラットは付図-2の斜め線で示したものになり、図 中に示すような $\alpha$ と $\beta$ が得られる。

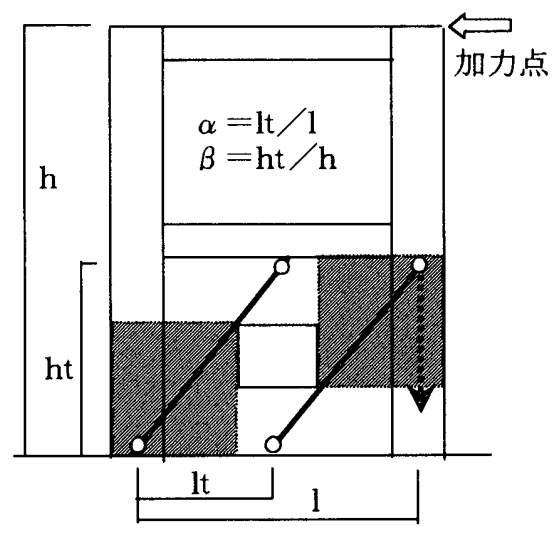

付図-2 ストラットの位置の設定 （1999年 2 月 8 日原稿受理, 1999年11月 1 日採用決定） 